Karolina Siwek

University of Jan Długosz in Częstochowa

karolina.siwek@onet.eu

\title{
A Flight of Tokarczuk Translators: Remarks on Collaboration and Cooperation
}

The responsibility of the translator is equal to that of the writer.

[Tokarczuk 2019]

\section{Olga Tokarczuk and 'her' 90 translators}

Olga Tokarczuk has had 90 translators prepare her texts into 37 languages, which gives 2-3 translators working in a one language pair. This fact raises many questions. Do they know each other? Do they collaborate? Do they face the same challenges during the translation? How much pressure of responsibility do they feel? Olga Tokarczuk herself has been a popular translated author in many European countries ${ }^{1}$ even before receiving the Nobel Prize. During this time, she created many relations with her translators and appreciated their job, which places her in the current trends. In recent years, authors seem to be more aware of the

The Czech Republic has been leading in translating Tokarczuk's works for more than 20 years. 
important role of literary translators. They appreciate their work because they understand that a translator is their ambassador and potential success in other countries is in translator's hands.

Authors are increasingly eager to meet translators, offer consultations, take part in meetings and, above all, recognise that translators are also entitled to the prizes awarded to authors. The same applies to Olga Tokarczuk. As a consequence of these new trends, the event called Gdańskie Spotkania Ttumaczy Literatury "Odnalezione w Ttumaczeniu"2 took place in April 2015 during which a meeting was organised of Olga Tokarczuk's translators, who had a chance to exchange opinions concerning their work on Tokarczuk's texts. Tokarczuk herself was also present, which gave an opportunity to learn her opinion about translators. She said that she agreed with the new tendency of rewarding the author and translator simultaneously, ${ }^{3}$ because the translated text is no longer only the author's property and becomes the property of the translator as well. Tokarczuk mentioned meeting with readers in foreign countries, where in the 'chemistry' with participants the main role is played by the translator rather than the author. The author is only 'an excuse' to discuss. According to Tokarczuk, the translator is also the most attentive reader who is able to point out all of the author's mistakes which were overlooked by the editors.

From the example of Tokarczuk's statements, a kind of special bond can be seen emerging between the author and the translator. Tokarczuk pointed out the fact of an emotional relationship appearing between the author and the translator, especially if this translator worked on more than one book. The situation when such a translator leaves their 'author' is for Tokarczuk a miserable experience equal to abandonment. During the meeting in Gdańsk, she mentioned a translator who was not eager to cooperate, and at the end of the translation process added a comment to the text that the author was wrong referring to one of the historical dates appearing in the book. Tokarczuk said that she felt offended.

The author/translator relationship seems to be crucial in preparing a reliable translation, but at the same time, it is not easy to work out. According to translators working with Tokarczuk, she is very cooperative and helpful.

2 "Pisarka i jej thumacze - Olga Tokarczuk || Odnalezione w thumaczeniu 2015", [online] https://www.youtube.com/watch? $\mathrm{v}=7 \mathrm{mB} 8 \mathrm{X}$ o_gguM\&feature=youtu.be, visited 21 January 2021.

3 The result of this preview is, for example, a meeting with the translators after the Nobel Prize. 
Nevertheless, the support of the author is sometimes insufficient for the translator. The author will not understand a translator whose problem is not to understand the content, but rather technical difficulties such as rendering the style in the target language, ageing of the language into which the translation is made, catching key nuances to be rendered in the translation to a foreign recipient, or those which can/should be omitted. Jennifer Croft, an English translator, commented on this issue: "When I have a question, Olga is always happy to help, but sometimes I feel like the best thing to do, if there's a sentence that is really just giving me a hard time is to ask the other translators rather than asking Olga." 4 It appears that in some cases, only another translator is able to be supportive and helpful. At the same time, the literary translator is aware of their responsibility, mentioned in the quote at the beginning of this article, for the text, representing the author, enriches native literature with novelties. This paper will be an attempt to investigate reasons for cooperating between literary translators who have prepared Tokarczuk's texts, to analyse how these relations are oriented and what the benefits of such relations are. Moreover, this article will also concern the assumptions proposed by sociology of translation which focuses on people involved in the process of translation instead of texts.

\section{2. "Collaboration" vs. "cooperation"}

This article deals with the relations between translators, which places it in the field of Translator Studies. In order to explore these relations, Marcel Thelen's [2016] outcomes concerning defining two categories of co-working between translators will be used and an attempt will be made to broaden this perspective to include subcategories to each of these two forms.

The term "collaborative translation" was coined by Sharon O'Brien [2011: 17] and can be understood as a situation when more than one translator works on one text. In this situation, collaboration appears between translators, and therefore the whole translation process becomes collaborative. This basic description gives a better perspective which can be combined with the Field Theory of Pierre Bourdieu [1993], which investigates the character of this collaboration within particular boundaries. Using this

\footnotetext{
4 "Translating the Future Finale: A Flight of Tokarczuk Translators", [25.09.2020], [online] www.centerforthehumanities.org/programming/a-flight-of-tokarczuk-translators, visited 21 January 2021.
} 
theory, literary translators can be defined as agents working in one field understood as literary translation. Agents have relations within the field which can be reconstructed by using the definitions of "collaboration" and "cooperation" as distinguished by Marcel Thelen [2016]. According to his outcomes, working on the same translation is closer to collaboration than cooperation because, despite the previous division of labour, all elements are merged and the final shape of the target text is established between the translators, which is at the core of the collaboration. There are many factors which may determine the decision on cooperation in a team of translators. O'Brien [2011: 18] lists three motivators: commercial, social and personal. In the case of commercial translation, she also mentions the issues of volume and short deadlines.

"Collaborative translation" was a concept used by the translators of the Bible, so it is not a new idea [ibidem: 17-20], but the fact is that nowadays, this way of work is popular in the translation of commercial texts. No one is surprised that several translators work on a single text at the same time and more and more CAT tools and databases are designed for them to facilitate their work. This manner of cooperation is clear and easy to organise. However, collaboration in the case of literary texts is surprising, disturbing and puzzling. The question is how collaboration looks in the case of literary texts. These types of texts are not so predictable. Splitting segments and preparation of terminology are not enough to get a polished translation and be successful.

In brief, collaboration and cooperation have the same objective, i.e. preparing one translation by several translators at the same time. However, the ways of achieving this goal differ. In cooperation, translators share the text/work and each translator works on their part/task, after which these are combined into a whole. This is a more mechanical and superficial process. Collaboration, on the other hand, may contain elements of cooperation, such as the sharing of a text, but at a later stage the translators working on a given translation consult each other about their decisions, strategies and doubts. This makes collaborative translation an in-depth co-working in which the whole text is the fruit of the work of all the people in the translation team.

As mentioned, the phenomenon of collaboration translation is an old invention used in the translation of the Bible from Hebrew into Greek. It caused the creation of different forms of collaboration and cooperation, and also the resulting evaluation of team work. Collaboration and cooperation 
between translators who work on a literary text can be organized and distributed in many different ways. Translation teams can be divided into two basic types - bilingual teams (usually tandems) and monolingual teams (tandems, but also multiperson teams). An example of a bilingual team is the case investigated by Bożena Żaboklicka [2019] concerning the Spanish translation of Witold Gombrowicz's texts: Ferdydurke and Ślub which were prepared by more than one translator at the same time. One of them was a native speaker of Spanish and the other a native of Polish. Both of them were similarly competent in the two languages involved in the translation process. This issue gave the opportunity to keep the balance between the original and the target text. In Żaboklicka's opinion, this kind of collaboration eliminated errors on the linguistic and cultural levels [ibi$d e m]$. In a similarly organized translation duet - Stanisław Barańczak and Clare Cavanagh worked on Wisława Szymborska's poetry. The outcome of this collaboration was also comparable. The target text was created within a strategy created together, based on the elimination of foreign elements in the translation [Brajerska-Mazur 2010]. This disturbed the intercultural balance, but the translation still remained the fruit of collaboration.

An example of working in a monolingual team is described by Krzysztof Filip Rudolf [2016]. It is the translation process of a novel titled English Passengers by Matthew Kneale. In the original text there are 21 narrators. In the translation, each of them had a dedicated translator. This kind of procedure allowed preserving the polyphony. Translators did not know the whole book and the fragments prepared for each other. It helped the translators to work independently [ibidem]. Another example is the duoMaria Kurecka and Witold Wirpsza who produced a translation of Doctor Faustus by Thomas Mann. At the same time, it is a case of combining the strength of two specialists from different fields, as Kurecka is a philologist and Wirpsza a poet. ${ }^{5}$ An interesting case of a monolingual translation team is also the Przebinda family - parents and their son - who in 2016 prepared a comprehensive translation of The Master and Margarita by Mikhail Bulgakov. The combined efforts of two generations made it possible to take the experience of the parents and combine it with the competence of the young man, resulting in a completely new quality of translation.

It should be mentioned that the struggle of this duo was described by Kurecka in her book Diabelne tarapaty [cf. Kurecka 1970]. 
Translations prepared in collaboration tend to be rather negatively received by translation theorists. Paul Kussmaul [2000] is a good case in point here. According to him, collaboration has a negative impact on personal creativity. Working in a team, a translator has no chance to be fully engaged. On the other hand, experience shows that teams or duets have worked out, and are able to prepare, correct and polished texts. ${ }^{6}$

\section{Subcategories of cooperation and collaboration faced with determinants}

Valuable sources of information about collaboration and cooperation between Tokarczuk's translators are meetings and video materials ${ }^{7}$ documenting them. One of them was mentioned at the beginning of this article. The second was organised as a conference called Translating the Future Finale: A Flight of Tokarczuk Translators. This meeting took place online on September 25, 2020. It was organised by Allison Markin Powell and Esther Allen, and sponsored by the Polish Cultural Institute New York, the Boston University Center for the Humanities, the Princeton University Program in Translation \& Intercultural Communication, and the East Central European Center at Columbia University. The participants were Olga Bagińska-Shinzato, Jennifer Croft, Barbara Delfino, Cristina Godun, Antonia Lloyd-Jones, Hikaru Ogura, Pavel Peč, Lothar Quinkenstein, Lisa Palmes, Maria Skakuj Puri, Ostap Slyvynsky, and Julia Wiedlocha. Olga Tokarczuk herself was not present. The fact of Tokarczuk's absence is crucial for the process of exchange of thoughts between the translators, who could speak freely and without regard to the author. The relation between translators is different from the relation of translator/author. From observing the meeting of translators/authors, it could be concluded that an author is like a teacher or boss, and translators serve him as students or employees. In such an atmosphere, there is no place for expression of opinion: the meeting in Gdańsk was held in the presence of the author, which

\footnotetext{
$6 \quad$ An example is the translation into Polish of three novels (Wir sind lockvögel, baby!; Die Ausgesperten; Die Liebhaberinnen) by Austrian Nobel Prize winner Elfriede Jelinek translated by Anna Majkiewicz and Joanna Ziemska [cf. Jelinek 2005a, 2005b, 2005c].

7 "Pisarka i jej thumacze - Olga Tokarczuk || Odnalezione w thumaczeniu 2015", op. cit.; "Translating the Future Finale: A Flight of Tokarczuk Translators", op. cit.
} 
turned out to be 'censorship' for the free exchange of views. Therefore, this paper and further conclusions are based mainly on the meeting from 2020.

The source material is quite modest, but it provides an initial insight into the issue of collaboration between a large number of Tokarczuk's translators, which would be impossible to achieve otherwise, as it would involve laborious access to fragmentary translator statements found in scattered sources or surveys and interviews among translators. Both options are difficult to pursue, although the second one might be considered in the future as an extension of the research on the topic of Tokarczuk's translators. The reference literature on the subject is also scarce, so I decided to try to independently categorise the different motivations of translators undertaking collaboration or cooperation.

A literary translator who undertakes translation must take into account the determinants that influence their work. In the face of these determinants, various subcategories of collaboration and cooperation can be distinguished.

\section{Subcategories of cooperation}

\subsection{Cooperation in research}

The first challenge is to do research before actual translation is done. Tokarczuk's texts are deeply rooted in history and culture. She writes about social problems firmly embedded in a particular space and time. At the same time, her texts refer to current issues in various countries and nations [Habrych 2020]. Her oeuvre can be divided into novels, like The Books of $J a c o b$ - strongly corresponding to the history and culture of many nations; and novels of engaged literature, involved in current social and political problems, such as Drive Your Plow Over the Bones of the Dead or House of Day, House of Night. ${ }^{8}$ The Books of Jacob are an attempt to combat the current Polish cultural paradigm. They take on the character of a historical novel, but are completely different from the proposal of Sienkiewicz. The multitude of intertextual games and the usage of historical texts, such as The Book of Zohar, ${ }^{9}$ make it necessary for the translator undertaking work

See Filip Matwiejczuk [2020], "Nowy Napis Co Tydzień \#049 / Olga Tokarczuk. Styl i poglądy", Nowy Napis. Liryka, epika, dramat. 49, [online] https://nowynapis. eu/tygodnik/nr-49/artykul/olga-tokarczuk-styl-i-poglady, visited 11 January 2021.

9 Ibidem. 
on such a novel to take the time to collect background material in order to fully delve into the world presented in a text.

This is the problem faced by the translators of the German tandem Lisa Palmes and Lothar Quinkenstein. Cooperation has allowed them to collect materials that are crucial in the case of understanding and starting the translation of The Books of Jacob. Palmes believes that such thorough preparation of the subject would be impossible for one person and would risk omitting significant aspects in the original text and, subsequently, in the translated text as well. The German tandem travelled to the Ofenbach archive to collect information about Jacob Frank. Nevertheless, this cooperation was not limited to Palmes and Quinkenstein. They were in constant contact with Jennifer Croft, an American translator, who translated Flights, and started working on The Books of Jacob in 2019. She worked alone, but in an interview, she admits that this kind of translation is not a job for one translator. She had contacted the German tandem many times over the phone, even though she is officially listed as the translator of The Books of Jacob into English. In the international translation team, the main topic was to discuss the sources from which they prepared for their translation work. Palmes, Quinkenstein and Croft exchanged views and supported each other. This kind of cooperation was thus mutual.

\subsection{Cooperation to divide the text}

Cooperation is most evident when translators separate pieces of text between themselves and then combine them into a whole. Importantly, in this case, everyone is focused on their own piece and there is no consultation with other translators. There can be two sources for this approach. Firstly, a close deadline and desire to speed up the work, and secondly, to preserve the distinctiveness of styles that are also distinct in the original text.

\subsubsection{Cooperation to save time}

Petr Vidlák is the first Czech Tokarczuk's translator who has translated her book for more than twenty years. He translated The Books of Jacob as one of the first translators in the world in 2016. As a result, Vidlák can be considered a professional regarding Tokarczuk's texts. He worked for a publisher, so in the case of Flights, the order came first and with it a deadline, which Vidlák could not meet. Faced with problems, he decided 
to ask another translator for help - Pavel Pec. ${ }^{10}$ Unfortunately, Pec did not reveal more details about how they co-worked. Nevertheless, knowing that the translators struggled with the deadline imposed by the publisher, and that Pec joined the project while it was in progress, it allows believing that the first part of Flights was entirely Vidlák's work, while the rest may have been the fruit of cooperation rather than a collaborative effort. It is highly possible that the translators shared the remaining text and worked on it without meticulous consultation.

\subsubsection{Cooperation to preserve the various styles}

The German tandem, at the beginning of their work on The Books of Jacob, decided to divide the original text into parts. ${ }^{11}$ Due to the different styles present in Tokarczuk's text and the need to preserve them in the translation, such division turned out to be the best idea. ${ }^{12}$

\subsubsection{Cooperation in looking for a publisher}

Publishing policy varies from country to country, and this affects the situation of a literary translator in the publishing process. Milica Markić Tokarczuk's translator into Slovenian, recalls ${ }^{13}$ that she translated three books, but had to look for a different publisher for each one. She carried out the search on her own, but, for example, the German tandem - Palmes and Quinkenstein joined forces. Lisa Palmes was offered a job on The Books of Jacob, but had to find a publishing house to undertake the publication herself. Finding a publisher for a book of a thousand pages is not easy because it involves significant capital for the publisher without the certainty that the book will sell. Palmes had previously worked in tandem with Quinkenstein on another book. The co-working went well, so she decided to ask him for help in finding a publisher for The Books of Jacob. After three years, they succeeded and could start translating. Previous suc-

\footnotetext{
10 Vidlák and Pec are only two of five other Czech translators of Tokarczuk.

11 Lisa Palmes, Lothar Quinkenstein, "Die Funken der Erlösung. Journal zur Übersetzung des Romans Die Jakobsbücher von Olga Tokarczuk (Kampa)”, [online] www. toledo-programm.de/journale/772/die-funken-der-erlosung-journal-zur-ubersetzungdes-romans-die-jakobsbucher-von-olga-tokarczuk-kampa, visited 21 January 2021.

12 A similar form of cooperation to preserve the various styles of the source text appeared in the case of the aforementioned novel English Passengers by Matthew Kneale. 13 Referring to the statement made during Gdańskie Spotkania Ttumaczy Literatury “Odnalezione w thumaczeniu” in 2015.
} 
cessful cooperation and a common search for a publisher made working in a tandem a natural consequence.

\section{Subcategories of collaboration}

\subsection{Collaboration in research}

Collecting materials in cooperation is only the first stage. It must be followed by verification and analysis, which already has the characteristics of collaboration. Therefore, in the case of Palmes and Quinkenstein, the initial cooperation evolved into a collaboration. They needed to analyse a vast amount of text about Jewish culture and religion. Working together gave the opportunity to prepare this kind of research quicker and more effectively, because each piece of information could be discussed and verified. Moreover, the Germans pointed out that there were some issues in the original text which forced them to go beyond their tandem. Most often they reached out to Croft and then collaborated to inter-lingually analyse the sources. In time, the exchange of information between Palmes, Quinkenstein and Croft stopped being limited to research archives and discussed the historical aspects.

\subsection{Collaboration to cope with intersexuality and understanding the original text}

During the conference in 2020, Croft quoted the words of the Ukrainian translator Ostap Slyvynsky, who mentioned that Olga Tokarczuk also did not work on the text of The Books of Jacob herself, but used texts of other authors upon which she built her story. Besides, she travelled a lot around Ukraine and talked to people, combining all these threads into one. And these threads were not just a product of her imagination, so in Croft's opinion, the translation of such a text cannot be a product of the imagination of one translator. A Romanian translator, Cristina Godun, who started working on The Books of Jacob, ${ }^{14}$ acknowledged that she had not yet consulted other translators, but at an early stage after understanding the complexity of the text, she sees such a need in the future. It allows assuming that she intended to collaborate in the cases of research and intertextual dilemmas in order to better understanding the complex original text. It is likely that Godun will seek support from the German tandem and from Croft, who

14 At the time of the online conference (25.08.2020), she has completed 10 pages. 
have already developed their strategies for doing not only research but also guessing intertextual tropes.

\subsection{Collaboration to recreate the style, language and provide cohesion}

Language and style are two issues that are immediately apparent when reading Tokarczuk's works and it can be considered as the second determinant. Tokarczuk's use of language and style prove to be a motivator for contact between translators:

The issue of language is interesting because it strongly draws attention to itself in this work. Here every thing, character, observation and movement must emerge before the perpetually bewildered observer. This can be seen in the short story under discussion. The subject of the text is an ordinary hotel, but the way the narrator talks about it brings to mind an image of an ancient sacred space (which the reader has to get used to, because in Tokarczuk's work every location appears to be a sacred place, a place beyond time) [Matwiejczuk 2020].

Recreating the proper style and language is crucial in capturing the essence of Tokarczuk's work. In The Books of Jacob, language needs to be aged to reflect the atmosphere of the original text. Then there is the multitude of language layers in the individual passages, which, although in the case of the German duo, were translated separately and were finally edited and polished together to provide cohesion. The style also has to be compatible with the climate of Austria-Hungary and Galicia in the original text. In the case of style and language, cooperation between translators took place within a single language group.

Jennifer Croft decided on collaboration with a previous Tokarczuk translator - Antonia Lloyd-Jones, who had already translated three books by Tokarczuk: Drive Your Plow Over the Bones of the Dead, House of Day, House of Night and Primeval and Other Times. Croft is American and Lloyd is British. It gives an opportunity to discuss the nuances between American and British English. Both intend to start permanent cooperation/collaboration and prepare a collection of short stories by Olga Tokarczuk. 


\subsection{Collaboration for personal reasons}

Analysing the list of all Tokarczuk's translators, ${ }^{15}$ it is not difficult to notice that in one language pair several translators appear, especially in the case of more popular languages e.g. German, English, French, Spanish, Italian, but also in languages of countries where Tokarczuk's works have been popular for years such as the Czech Republic, or culturally close e.g. Russia, Ukraine, Bulgaria, Hungary.$^{16}$ A change of translator is sometimes due to a publisher's policy, especially where Tokarczuk's work has been known and translated for years (Czech Republic). The translator is expected to do the job and nothing more. It is just a job. Sometimes, however, the 'abandonment' of an author is not due to publishing policy or the enormity of the work resulting from a particular interest in a given author. Sometimes the abandonment is related to the fifth determinant of a translator's work, i.e. the failure to establish a relationship with the texts, to enter and feel Tokarczuk's work. The failure to establish this special relationship results in the abandonment of translation work in favour of a given author. ${ }^{17}$ Such abandonment resulting from a lack of connection with translation work in favour of Tokarczuk occurred, for example, in the case of the German translator Esther Kinsky, who refused to translate The Books of Jacob because she had started writing her own texts and this was her priority. It can be inferred that she did not form a relationship with Tokarczuk's texts, she did not delve into them deeply enough to form such a relationship, so she had no difficulty in rejecting further work. Having received the commission, however, she passed it on to Lisa Palmes, who later formed a tandem with Lothar Quinkenstein. They realised that working on an extended text requires proper immersion, which, with the amount of information, can lead to confusion and lost threads. Working in a tandem gives an oppor-

15 The list was created based on data from the National Library. See Stowarzyszenie Tłumaczy Literatury [2019], "Książki Olgi Tokarczuk na świecie”, [online] http://stl. org.pl/ksiazki-olgi-tokarczuk-na-swiecie/?fbclid=IwAR35LoZ6532vnlB__bOuG4IYNiBLe8ZvGL_XL9TGYd7tpZdlDWtp-F1PnnY, visited 22 April 2021.

16 See Maciej Piotrowski [2020], "Tokarczuk po Noblu cz. 1. Wydaje się na świecie", [online] https://rozstaje.art/aktualnosc/tokarczuk-po-noblu-wydaje-sie-na-swiecie-cz-1, visited 21 January 2021; idem, "Tokarczuk po Noblu cz. 2. Wydaje się na świecie", [online] https://rozstaje.art/aktualnosc/tokarczuk-po-noblu-cz-2-wydaje-sie-na-swiecie, visited 21 January 2021.

17 During a meeting in Gdańsk in 2015, Olga Tokarczuk mentioned that such abandonments happen to her and each time she perceives it as a severance of an emotional bond, a sense of loss, maybe even a kind of betrayal. 
tunity to consult with a person equally involved in a given author's text when doubts arise. Two translators interact with the text simultaneously, and if one feels lost in the vast amount of information to process, there is a partner to support and advise. Such consultations have had a significant impact on improving style and eliminating errors. Entering into collaboration helps get rid of the feeling of loneliness and being lost in the text, intertextuality, or research. There is a motivator in moments of doubt. ${ }^{18}$

There is also a kind of abandonment in the case of Antonia Lloyd-Jones. The British translator prepared three books by Tokarczuk (Drive Your Plow Over the Bones of the Dead, House of Day, House of Night and Primeval and Other Times) and then she did not undertake the translation of The Books of Jacob. There is no clear comment from Lloyd-Jones herself as to what the reason was. Nevertheless, from her statements, it seems that each of Tokarczuk's books represents a different form and style. ${ }^{19}$ Looking at Lloyd-Jones's translation output to date, it is likely that the reason why she did not translate The Books of Jacob was due to the fact that the style and form did not appeal to her. A good literary translation cannot be done without delving into the text. Nonetheless, Lloyd supports Jennifer Croft (she worked on The Books of Jacob) in her work. They are

18 However, it is evident that not every translator will make an effective tandem/ group with another translator. Palmes points out that, throughout the process, she and Quinkenstein had had similar thoughts, remarks and observations. Translators must be characteristically matched to work together successfully and form a good team. For a group's work to be a success, it must also be properly organised and the result oriented. During the conference and also in their translation diary, Palmes and Quinkenstein described the process of translation and the organization of this work. They adopted a strategy of dividing the text, but after translation, they consulted with each other on the style used in the translation to make sure that the different elements fit together. This was exactly the same style of work as in a previous collaboration. They emphasize that the division was mainly due to the natural division of the original text, which is not homogeneous. Palmes notes that working in this way significantly prolongs the translation process but raises fidelity. The mentioned diary is available [online] https://www.toledo-programm.de/journale/772/die-funken-der-erlosung-journal-zur-ubersetzung-des-romans-die-jakobsbucher-von-olga-tokarczuk-kampa, visited 21 January 2021.

19 This was the opinion of Lloyd-Jones in an interview with RMF radio after Tokarczuk was honored with the Nobel Prize. See "Tłumaczka Tokarczuk na angielski: Olga to Stanley Kubrick świata", [online] https://www.rmf24.pl/kultura/news-tlumaczkatokarczuk-na-angielski-olga-to-stanley-kubrick-swi,nId,3270905, visited 21 January 2021. 
in frequent contact and envisage joining forces to translate Tokarczuk's short stories. Joining forces will also be crucial in getting publishers, as Polish literature is little known in English and finding a publisher for Tokarczuk will be a challenge.

\section{Benefits of cooperation and collaboration according to translators}

A complex network of connections emerges between the Tokarczuk translators. They work together in different configurations, i.e. in one language pair and between different language pairs. Nevertheless, not every translator is made to work in a tandem, as in the case of Palmes and Quinkenstein. A well-matched relation has a chance of success, otherwise the collaboration makes no sense and the translators will stumble over each other. It is very important to be able to adapt to a partner, to think in a similar way and to be determined to pursue a common goal which is the overriding issue. Co-working is a source of motivation and support in emerging difficulties. In order to work harmoniously, translators have to adjust and establish rules for co-translation. They themselves must also determine whether they are translating on the basis of collaboration or cooperation.

Collaboration and partially cooperation eliminate stylistic and cultural mistakes. It is also easier to render the polyphony of the text and its potentially complex character. It turns out that a well-chosen tandem/group does not compete against each other and does not limit the other translator's creativity. The common goal, as a superior value, stimulates the translators to cooperate and consult with each other in order to refine the best possible translation. The translation is consistent with the original, readable to a foreigner and correct. It is definitely a positive thing to eliminate frustration and loneliness, which can overwhelm a translator working without support. There is the issue of mental comfort ensured by the awareness of having a partner equally involved in the text. In the case of commercial translations, the work of a team of translators is supposed to save time and do as much work as possible in the shortest possible time. Palmes rejects this approach in the case of literary translation. In her opinion, working in a tandem takes more time than working on your own, because a translator has to add the time spent on consultations; however, for the sake of a good end result, this time is worthwhile. 
Similar advantages of cooperation are seen by other translators contacting their colleagues in the area of other language pairs. The sense of support with difficulties, motivation and background in the form of advice from colleagues/translators already working on a given subject or author is invaluable. No one understands a translator as well as another translator, especially if they are struggling with similar problems, which are quite similar despite different languages, because all translations of Tokarczuk's texts were done at about the same time.

\section{Conclusions}

In conclusion, the main motivators for collaboration or cooperation, which can be reconstructed are the determinants affecting the work of a literary translator: the research needed, style and language of the text, deadline, cooperation with the publisher and, above all, the personal relationship between the translator and the text. Collaboration usually takes place within the same language pair. The main motivator in the case of Tokarczuk's texts is research (mainly in the case of The Book of Jacob) and style (practically every Tokarczuk text). All these determinants contribute to the responsibility that the translator has regarding the author and the text.

At the conference in August 2020, Tokarczuk's translators agreed that they were willing to use each-other's knowledge. It turns out that the image of a literary translator working in seclusion and isolation is a thing of the past. If there is an opportunity to get help, they are eager to use it. New technologies and ease of communication are conducive to frequent telephone, e-mails and social media contacts. Translators can be in constant touch. The idea of collaboration, known from the time of the translation of the Bible is returning to favor in a new refreshed form. It remains to be seen whether literary translation will benefit from it on a large scale. Nevertheless, the theory condemning teamwork as a death knell to creativity discourages putting it into practice. What benefit can collaboration and cooperation during the translation process bring to literary translation? Perhaps translations created in this way have a chance to be close to the canonical ones. 


\section{References}

Bourdieu, P. (1993), The Field of Cultural Production: Essays on Art and Literature, Polity Press, Cambridge.

Brajerska-Mazur, A. (2010), "Strategie translatorskie w przekładzie problemów kulturowych z wierszy Wisławy Szymborskiej”, Pamiętnik Literacki. 3: 111-137.

Habrych, S. (2020), “Coś jest ze światem nie tak. Recepcja twórczości Olgi Tokarczuk po otrzymaniu Literackiej Nagrody Nobla", Postscriptum Polonistyczne. 1(25): 117-118, https://doi.org/10.31261/PS_P.2020.25.08.

Jelinek, E. (2005a), Amatorki, W.A.B., Warszawa.

Jelinek, E. (2005b), Jesteśmy przynęta, kochanie!, W.A.B., Warszawa.

Jelinek, E. (2005c), Wykluczeni, W.A.B., Warszawa.

Kurecka, M. (1970), Diabelne tarapaty, Wydawnictwo Poznańskie, Poznań.

Kussmaul, P. (2000), Kreatives Übersetzen Tübingen, Tübingen, Stauffenburg.

Matwiejczuk, F. (2020), "Nowy Napis Co Tydzień \#049 / Olga Tokarczuk. Styl i poglądy", Nowy Napis. Liryka, epika, dramat. 49, [online] https://nowynapis. eu/tygodnik/nr-49/artykul/olga-tokarczuk-styl-i-poglady, visited 11 January 2021.

O’Brien, S. (2011), “Collaborative translation”, Handbook of Translation Studies. 2: 17-20, https://doi.org/10.1075/hts.2.col1.

Palmes, L., Quinkenstein, L., "Die Funken der Erlösung. Journal zur Übersetzung des Romans Die Jakobsbücher von Olga Tokarczuk (Kampa)", [online] www. toledo-programm.de/journale/772/die-funken-der-erlosung-journal-zur-ubersetzung-des-romans-die-jakobsbucher-von-olga-tokarczuk-kampa, visited 21 January 2021.

Piotrowski, M. (2020), “Tokarczuk po Noblu cz. 1. Wydaje się na świecie”, [online] https://rozstaje.art/aktualnosc/tokarczuk-po-noblu-wydaje-sie-na-swiecie-cz-1, visited 21 January 2021.

Piotrowski, M. (2020), “Tokarczuk po Noblu cz. 2. Wydaje się na świecie”, [online] https://rozstaje.art/aktualnosc/tokarczuk-po-noblu-cz-2-wydaje-sie-na-swiecie, visited 21 January 2021.

"Pisarka i jej thumacze - Olga Tokarczuk || Odnalezione w thumaczeniu 2015", [online] https://www.youtube.com/watch?v=7mB8Xo_gguM\&feature=youtu. be, visited 21 January 2021.

Rudolf, K. F. (2016), "Wielogłosowa powieść w translatorskim wielogłosie, czyli Anglicy na poktadzie Matthew Kneale'a”, Przektadaniec. 32: 128-144, https:// doi.org/10.4467/16891864PC.16.008.6548. 
Stowarzyszenie Tłumaczy Literatury (2019), "Książki Olgi Tokarczuk na świecie", [online] http://stl.org.pl/ksiazki-olgi-tokarczuk-na-swiecie/?fbclid=IwAR35 LoZ6532vnlB_bOuG4IYNiBLe8ZvGL_XL9TGYd7tpZdlDWtp-F1PnnY, visited 22 April 2021.

Thelen, M. (2016), "Collaborative translation in translator training", Konin Language Studies. 4(3): 253-269.

"Tłumaczka Tokarczuk na angielski: Olga to Stanley Kubrick świata", [online] https://www.rmf24.pl/kultura/news-tlumaczka-tokarczuk-na-angielski-olgato-stanley-kubrick-swi,nId,3270905, visited 21 January 2021.

Tokarczuk, O. (2019), "[Musings] How Translators Are Saving the World", Korean Literature Now. 44, [online] https://koreanliteraturenow.com/essay/musings/ olga-tokarczuk-musings-how-translators-are-saving-world, visited 21 January 2021.

"Translating the Future Finale: A Flight of Tokarczuk Translators", (25.09.2020), [online] www.centerforthehumanities.org/programming/a-flight-of-tokarczuktranslators, visited 21 January 2021.

Żaboklicka, B. (2019), "Wybrane problemy przekładu w dwujęzycznym tandemie na przykładzie tłumaczenia różnych utworów Witolda Gombrowicza na hiszpański”, [online] http://www.muzeumgombrowicza.pl/pl/czytaj/33/56/ kongres-tlumaczy-gombrowicza/teksty, visited 21 January 2021.

\begin{abstract}
Olga Tokarczuk's texts became eagerly translated even before she was honoured with the Nobel Prize. As a result, many literary translators have dealt and continue to deal with her texts. This paper will be an attempt to investigate reasons for co-working between translators, to analyse how these relations are oriented and what the benefits of such relations are. The research is based on the outcomes of Sharon O'Brien and Marcel Thelen concerning collaboration and cooperation between translators and on research material recorded at conference: Translating the Future Finale: A Flight of Tokarczuk Translators. O'Brien's and Thelen's conclusions are expanded with subcategories which gives a better perspective on the motivation for collaboration and cooperation between Tokarczuk's translators. Co-working gives translators a sense of support, which is reflected in the quality of the translated text.
\end{abstract}

Keywords: Tokarczuk, translator, collaboration, cooperation, tandem 


\section{STRESZCZENIE}

\section{O tlumaczach tekstów Tokarczuk. Uwagi o współpracy}

\section{i współdziałaniu}

Teksty Olgi Tokarczuk były chętnie thumaczone, zanim uhonorowano ją Nagrodą Nobla. W rezultacie jej twórczością zajmowało i nadal zajmuje się wielu tłumaczy literatury, którzy niejednokrotnie wspólnie pracują nad poszczególnymi tekstami i problemami. Niniejszy artykuł stanowi próbę zbadania przyczyn, przebiegu i korzyści wspólnej pracy. Analiza opiera się na wynikach badań Sharon O’Brien i Marcela Thelena dotyczących współpracy (collaboration) i współdziałania (cooperation) między tłumaczami, a także na materiale badawczym zarejestrowanym podczas konferencji pn. Translating the Future Finale: A Flight of Tokarczuk Translators. Wnioski O'Brien i Thelena poszerzono o podkategorie, co umożliwia pełniejszy ogląd motywacji do współpracy i współdziałania tłumaczy Tokarczuk. Poczucie wsparcia uzyskane przez tłumaczy przekłada się na jakość tłumaczonego tekstu.

Słowa kluczowe: Tokarczuk, tłumacz, współpraca, współdziałanie, tandem 